\title{
Do Business Regulations Promote Growth in Low-income Countries?
}

\author{
Bogdan Dima1 | Ştefana Maria Dima ${ }^{2 *}$ \\ ${ }^{1}$ Faculty of Economics and Business Administration, West University of Timisoara, Timişoara, Romania \\ 2 East European Center for Research in Economics and Business (ECREB), Faculty of Economics and Business \\ Administration, West University of Timișoara, Timişoara, Romania
}

\begin{abstract}
The present article addresses the complex web of interactions between the architecture and quality of the business regulatory setting and economic growth. Thus, we aim to advance a two-fold contribution to the literature: we methodologically account for the uncertainty related to possible alternative explanations for growth processes, by means of 'Bayesian Model Averaging'; and we assess the impact of business environment on growth, involving the descriptors reflected by Country Policy and Institutional Assessment. These indicators benefit from a pronounced 'in-field' nature and reflect a large variety of possible public policies. The results suggest a statistically significant positive relationship between the overall quality of business regulatory environment and growth. This outcome is found to be robust to various choices of priors' structures. Moreover, the outcome's estimated amplitude largely declines once the endogeneity is considered.
\end{abstract}

Key words: economic growth, business regulations, CPIA, low-income countries, Bayesian Model Averaging

JEL Classification: C11, F43, K20

\section{INTRODUCTION}

The neo-institutionalism framework allows for the identification of a complex web of interactions between the architecture and quality of the regulatory set and economic growth. As Dawson (2006: 490) argues: "it is reasonable to think that regulation may affect an economic agent's ability to engage in voluntary exchange and the efficiency with which resources are used in an economy. Thus, we might expect that the level of regulation in a country is related to indicators of long-run economic performance such as the level of investment or per capita income growth".

At least two types of transmission channels can be involved. First, the regulatory framework defines the 'rules of the game'. If this framework is stable and predictable, the economic agents can set their decisions in a low-uncertainty environment and, hence, can engage themselves in long-run projects. Second, if such framework incorporates various 'positive externalities', it can foster entrepreneurial initiative and support human resources' mobility. Thus, the quality of regulations can be directly linked to growth engines. Meanwhile, regulations impact the standard determinants of growth, such as capital accumulation, research and development processes or labor market. In consequence, one can expect a synergic impact of regulations, by means of multiple key determinants of growth.

\footnotetext{
${ }^{*}$ Corresponding Author, e-mail: stefana.dima@e-uvt.ro
} 
Indeed, several empirical evidences in the literature suggest that regulations matter in explaining sustainable growth. For instance, Beugelsdijk's (2010) findings suggest that differences in economic growth in Europe can be explained by differences in entrepreneurial culture, albeit, mostly in an indirect way. For a data sample of 172 countries, Haidar (2012) finds that, on average, each business regulatory reform is associated with a 0.15 percentage point increase in growth rate of GDP. Similarly, Djankov et al. (2006) finds that, for 135 countries, recovering from the worst quartile of business regulations to the best implies a 2.3 percentage point increase in annual growth.

However, not all public policies with regulatory content have the same impact on growth. For instance, Kolko et al. (2011) find that business climate indices, which focus on productivityrelated variables, have essentially no predictive power for economic growth. In contrast, business climate indices focusing on taxes and costs predict growth of employment, wages, and Gross State Product. Furthermore, Hanusch (2012) involves the Doing Business index components and finds evidences suggesting that the focus on indicators related to credit and the enforcement of contracts is the most important factor. Indicators related to cost have the largest potential for fostering growth. Messaoud and Teheni (2014) find as well a robust link between regulation indices and economic growth, except for Trading Across Borders and Dealing with Construction Permits components of Doing Business index. However, they conclude that regulation indices and control variables do not matter in terms of growth induction in Africa. Dawson (2006) finds that credit market regulations affect growth, primarily through the investment channel, while business regulation has a significant effect on growth, via the total factor productivity channel.

Moreover, countries are far from adopting an uniform set of regulations and large differences between them are in place. Just to provide an example, Nicoletti and Scarpetta (2003), by using a large new dataset on product market regulation, show that regulatory policies in OECD nations have become more dissimilar in relative terms over time. They explain this finding by different starting points and different reform speeds. Their data also show that this divergence in the regulatory settings lines up with the divergent growth performance of OECD nations; in particular the poor performance of large Continental economies relative to that of the United States. Hence, if the nature of the regulatory framework is really relevant in explaining growth, one might expect large spectra of effects induced by changes in this framework on growth.

Thus, any model aiming to describe the impact of regulations should account for this potential heterogeneity of associated effects. Supplementary, it can be argued that there might be a tradeoff between the number of regulations and, respectively, their quality. On one hand, regardless of the quality of regulations, too many regulations can be detrimental for growth. Surely, this argument should be considered with caution (for instance: Busse and Groizard, 2008, show that excessive regulations restrict growth, through the channel of Foreign Direct Investments, only in the most regulated economies; Dawson, 2006, finds that an increased complexity of the regulatory framework is negatively related to private investment and positively related to government investment). However, at a general level of discussion, it can be considered that 'excessive' regulations burden the free economic initiative and so it might harm growth. On another hand, at a comparable level of regulatory pressure, the differences between countries in terms of growth can be, inter alia, explained by differences in the quality of regulations (as pointed out by findings, such as Haltiwanger et al. (2014), suggesting that, even after controlling for industry and size effects, there remain significant differences in job flows across countries, which could reflect differences in labor market regulations).

Similarly, Djankov et al.(2002) find (consistently with the public choice approach emphasizing rent extraction by politicians) that countries with less limited, less democratic, and more interventionist governments regulate entry of start-up companies more heavily, even controlling the level of economic development. As the authors explain "entry is regulated more heavily by less 
democratic governments, and such regulation does not yield visible social benefits" (Djankov et al., 2002:35).

Finally, the regulations are not adopted in an empty societal space. Rather, this space is populated by various formal and informal, macro and grassroots institutions. Also, these institutions are the outcome of evolutionary historical processes. For instance, Botero and al. (2004) find that the historical origin of a country's laws shapes its regulation of labor and other markets and that the countries have pervasive regulatory styles inherited from the transplantation of legal systems.

Both 'policies' and 'institutions' influence growth and, so, any model of policies' impact on growth cannot be 'context-free': it should account for the influence of the existing institutional surround. Though, while policies can be adjusted on 'short-run', institutions usually evolve on 'long-run'. During 'institutional adjustment' period, the social landscape can be substantially modified and several endogenous or exogenous shocks might occur. Thus, there is no guarantee that the presence of a certain institution will always generate the same outcomes of social decisions. Consequently, the impact of policies, as modulated by institutions, is not necessarily uniform. For instance, there is no warranty that a democratic arrangement of social institutions will always leads to public decisions that are socially optimal; while, correlatively, it is not clear, on an ex ante basis, that an authoritarian regime will always adopt 'bad' policies. But what really matters is the possibility to operate corrections to the negative consequences of 'bad' policies and, hence, the extent to which the institutional arrangements allow for feed-back corrective reactions from the private sector and civil society. Following such arguments, one can expect a large variety of synergic effects between institutions and policies in growth processes.

We aim to advance a two-fold contribution to this stream of literature. First, we methodologically account for the uncertainty related to possible alternative explanations for growth processes by involving a 'Bayesian Model Averaging'. Second, we assess the impact of business environment on economic growth. Even ifa large body of literature employs World Bank'sDoing Business index, we see this measure as not immune to various criticisms. Hence, we involve other indicators for the quality of policies, namely the descriptors reflected by Country Policy and Institutional Assessment. These indicators benefits from a pronounced 'in-field' nature and reflects a large variety of possible public policies.

\section{METHODOLOGY}

Growth is a multi-dimensional process. It depends on resources and geography, technology and human capital. But it depends as well on institutions and politics, culture and social norms and behaviors. It is shaped by long-run historical forces and it is affected by short-run shocks. Furthermore, growth influences almost any aspect of the societal life and feed-back and feedforward mechanisms link growth to any major economic and social variable. Hence, the task of modeling growth faces a large degree of uncertainty in regard to the 'true' model that should be involved. Still: "Standard statistical practice ignores model uncertainty. Data analysts typically select a model from some class of models and then proceed as if the selected model had generated the data. This approach ignores the uncertainty in model selection, leading to over-confident inferences and decisions that are more risky than one thinks they are" (Hoeting et al., 1999:382).

Let consider the following standard model of economic growth:

$$
y=\alpha_{\gamma}+\beta_{\gamma} x_{\gamma}+\varepsilon, \quad \varepsilon \square N\left(0, \sigma^{2} I\right)
$$

Here, $y$ stands for the dynamic of economic output, $x$ is a matrix of economic growth determinants, $\alpha_{\gamma}$ is a constant term, while $\varepsilon$ is a shock to growth modeled as a normal i.i.d. error term with variance $\sigma^{2}$. 
A major issue for the estimation of such model relates to the existence of a substantially large list of potential economic growth determinants. Such list may include both 'hard' economic and social variables, but also 'soft' institutional, cultural and behavioral ones. This raises several subsequent questions, which are critical for the proper specification of growth models: Which variable $x_{r}$ from the set $\{x\}$ should be included in the 'true' model? How important is actually an individual variable in explaining the mechanisms of growth?

The 'Bayesian Model Averaging' (BMA) provides a way for relevant variables identification and dealing with model uncertainty, by estimating models for all possible combinations of $\{x\}$ and, further, by constructing a weighted average over all of them (see, as an example for the application of this methodology in the context of growth, Horvath, 2013). Hence, if the full set of possible explanatory contains $K$ variables, there are $l=2^{K}$ variable combinations and, thus, $M_{1}, \ldots, M_{l}$ models to be considered. The specific model weights derive from posterior model probabilities that stand up from Bayes' theorem:

$$
p\left(M_{\gamma} \mid y, x\right)=\frac{p\left(y \mid M_{\gamma}, x\right) p\left(y \mid M_{\gamma}\right)}{p(y \mid x)}=\frac{p\left(y \mid M_{\gamma}, x\right) p\left(y \mid M_{\gamma}\right)}{\sum_{s=1}^{l} p\left(y \mid M_{\gamma}, x\right) p\left(M_{s}\right)}
$$

Since ${ }^{p(y \mid x)}$ denotes the integrated likelihood, which is constant over all models, the posterior model probability (PMP) $p\left(M_{\gamma} \mid y, x\right)$ appears to be proportional to the marginal likelihood of the model $p\left(y \mid M_{\gamma}, x\right)$ multiplied with a prior model probability $p\left(M_{\gamma}\right)$ reflecting prior beliefs about how probable is model $M_{\gamma}$ before any data examination. From here, one can derive the PMPs and, thus, the model weighted posterior distribution for any statistic $\theta$ (such, for instance, the one for parameters $\beta$ ):

$$
p(\theta \mid y, x)=\sum_{\gamma=1}^{l} p\left(\theta \mid M_{\gamma}, y, x\right) p\left(M_{\gamma} \mid x, y\right)
$$

In addition, the 'unconditional coefficients' are defined as:

$$
E(\beta \mid y, x)=\sum_{\gamma=1}^{l} p\left(\beta_{\gamma} \mid M_{\gamma}, y, x\right) p\left(M_{\gamma} \mid x, y\right)
$$

These coefficients represent a weighted average over all models, including those where this particular coefficient was restricted to zero. By contrast, the 'conditional coefficients' are 'conditional on inclusion', i.e. they represent a weighted average only over those models, where its regressors were included.

Finally, the associated posterior variance is equal with:

$$
V(\beta \mid y, x)=\sum_{\gamma=1}^{l} p\left(M_{\gamma} \mid y, x\right) V\left(\beta \mid M_{\gamma}, y, x\right)+\sum_{\gamma=1}^{l} p\left(M_{\gamma} \mid y, x\right)\left(E\left(\beta \mid M_{\gamma}, y, x\right)-E(\beta \mid y, x)\right)^{2}
$$

This posterior variance includes both the weighted average of the estimated variances of the individual models, as well as the weighted variance in estimates of coefficients across different models. Hence, even if there is obtained precise estimates in all the models, one might end up with considerable uncertainty about the parameter, if those estimates are very different across specifications (Moral-Benito, 2015).

It can be noticed that the choice of the prior model probability is critical in obtaining plausible estimates. Several solutions are usually considered. One is the so-called 'uniform prior probability' designed to reflect the lack of prior knowledge $p\left(M_{\gamma}\right) \propto 1$. A second alternative, based on an 
'inclusion and exclusion probabilities' approach, corresponds to the 'binomial model prior'. It places a common and fixed inclusion probability $\theta$ on each of the regressors. Hence, the prior probability of a model of size $k$ is $p\left(M_{\gamma}\right) \propto \theta^{k_{\gamma}}(1-\theta)^{K-k_{\gamma}}$. Subsequently, the expected model size is $\bar{m}=K \theta$ and the 'fixed' prior is $p\left(M_{\gamma}\right) \propto\left(\frac{\bar{m}}{K}\right)^{k_{\gamma}}\left(1-\frac{\bar{m}}{K}\right)^{K-k_{\gamma}}$. However, one can observe that the fixed common parameter in the binomial prior is centering the mass of its distribution quite close to the prior model size. A random approach grounded on beta-binomial model prior, in the case of which the inclusion probability is drawn from a beta distribution, provides a less 'tight' prior distribution.

In correspondence to her / his prior beliefs on the appropriate model, one can choose among such options, in order to specify the prior model probability. Still, obtaining posterior distributions also requires the specification for the priors on the model parameters. More exactly, it should be specified a prior belief about the normal distribution of the coefficients with a certain specified mean and variance. A 'conservative' set of the prior mean is equal to zero, while their variance structure can be defined according to Zellner's $g$ hyper-parameter. Thus:

$$
\beta_{\gamma} \mid g \square N\left(0, \sigma^{2}\left(\frac{1}{g} x_{\gamma}^{\prime} x_{\gamma}\right)^{-1}\right)
$$

The hyper-parameter encapsulates the uncertainty related to coefficients being close to zero, while posterior distribution of coefficients reflects this prior uncertainty: with a given $g$, this distribution might follow, for instance, a $t$-distribution with expected value $E\left(\beta_{\gamma} \mid y, x, g, M_{\gamma}\right)=\frac{g}{1+g} \hat{\beta}_{\gamma}$ (with $\hat{\beta}_{\gamma}$ being the standard OLS estimator for model $\gamma$ ). Hence, the expected value of coefficients might be seen, in this case, as a convex combination of OLS estimator and prior mean (zero) and changes in $g$ will lead to changes in this value.

This framework allows the estimation of the marginal likelihood $p\left(y \mid M_{\gamma}, x, g\right)$ with a size penalty factor adjusting for model size $k_{\gamma}$.

Of course, the critical issue here is the choice of $g$. One frequently used choice is the so-called 'unit information prior' (UIP), which sets $g=N$ as a common value for all models. Other used settings are: $g=\max \left(N, K^{2}\right)$ ("BRIC") and $g=\log (N)^{3}$ ("Hannan-Quinn").

A particular method is represented by the selection of an "Empirical Bayes (Local)" $g$.

This implies a model-specific $g_{\gamma}$ estimated via maximum likelihood: $g_{\gamma}=\max \left(0, F_{\gamma}-1\right), F_{\gamma}=\frac{R_{\gamma}^{2}\left(N-1-k_{\gamma}\right)}{\left(1-R_{\gamma}^{2}\right) k_{\gamma}}$ (with $R_{\gamma}^{2}$ being the OLS R-squared of model $M \gamma$ ).

Finally, there is also a "Hyper- $g$ prior" method related to a beta prior on the shrinkage factor with $p\left(\frac{g}{1+g}\right)=B\left(1, \frac{a}{2}-1\right), 2<a \leq 4$. A value of $a=4$ implies prior shrinkage to be uniformly distributed over $[0,1]$; while $a \rightarrow 2$ implies a mass close to unity. Here, there are two versions that guarantee asymptotic consistency. The first one sets the prior expected shrinkage factor equivalent to the 'UIP' prior, while the second one sets it at 'BRIC'.

A key point in the selection of the priors relates to the fact that, in large growth models, there is a relatively high degree of uncertainty: while for standard determinants of growth is somehow easier to formulate ex ante evaluations, the impact of institutions, policies and culture on growth is less straightforward. Eicher et al. (2011) find that the UIP with uniform model prior generally 
outperform the other priors considered in their study. It also identified the largest set of growth determinants. Hence, for our baseline results we involve this UIP/uniform specification.

We use the implementation of the BMA from Feldkircher and Zeugner (2015). For the Bayesian model sampling, we take 100000 burn-ins and 1000000 draws, yielding to a sufficiently high correlation between the analytical and posterior model probabilities. An MC3 'birth-dead' sampler is considered: one of the $K$ potential covariates is randomly chosen; if the chosen covariate forms already part of the current model $M_{i}$, then the candidate model $M_{j}$ will have the same set of covariates as $M_{i}$ but for the chosen variable ('dropping' a variable). If the chosen covariate is not contained in $M_{i}$, then the candidate model will contain all the variables from $M_{i}$ plus the chosen covariate ('adding' a variable) (for more details on the implementation, see Zeugner, 2011 and Feldkircher and Zeugner, 2015).

\section{INTERNATIONAL DATA}

We aim to evaluate the potential impact exercised by the individual business regulatory framework in a growth context for a dataset of 65 low-income (and lower-middle income) countries (as classified, in 2015, according to World Bank criteria) (see Table A.1. from the Appendix for the list of these countries).

In assessing the relationships between the quality of business regulations and growth, our first task is to consider a proper measure of the business regulatory environment (and other growthoriented public policies). For this, we involve the components of World Bank's International Development Association (IDA) Resource Allocation Index, which is based on the results of the annual Country Policy and Institutional Assessment (CPIA) exercise that covers the IDA eligible countries. The CPIA assesses the quality of a country's current policy and institutional framework. In this context, "'quality' refers to how conducive that framework is to fostering poverty reduction, sustainable growth, and the effective use of development assistance" (World Bank, 2014:1). Since we are mainly interested in public policies aiming to support growth, we choose these indicators rather than alternative assessments (such as, for instance, the Ease of Doing Business). The key argument is related to that: "The criteria focus on policies and institutional arrangements, the key elements that are within the country's control, rather than on actual outcomes (for example, growth rates) that are influenced by elements outside the country's control" (World Bank, 2014:5). In other words, our goal is to appraise the impact exercised by the individual quality of public policies in sustaining growth in low-income countries and, hence, we choose to involve those explanatory variables able to describe the design of these policies, rather than their outcomes. Also, we are aware of the existence of some important criticism in respect to Doing Business index (see, for instance, the arguments from Arruñada, 2010 - according to which this index methodology promotes biased measurements that impede proper consideration of the essential trade-offs in the design of formalization institutions; also, Irwin, 2009, argues that Doing Business results are based entirely on rankings that imply an equal spread between consecutive ranks and effectively ignores shortcomings in the research methodology. Hence, the derived rankings can mislead countries that have made an effort to reform).

By contrast, the CPIA business regulatory environment variable "assesses the extent to which the legal, regulatory, and policy environment helps or hinders private business in investing, creating jobs, and becoming more productive. The emphasis is on direct regulations of business activity and regulation of goods and factor markets. Three sub-components are measured: (a) regulations affecting entry, exit, and competition; (b) regulations of ongoing business operations; and (c) regulations of factor markets (labor and land)" (World Bank, 2014: 19).

The CPIA rates countries against a set of 16 criteria grouped in four clusters: (a) economic management; (b) structural policies; (c) policies for social inclusion and equity; and (d) public sector management and institutions. All criteria within each cluster receive equal weight, and each 
cluster has a 25 percent weight in the overall score, which is obtained by averaging the average scores of the four clusters. For each of the 16 criteria countries are rated on a scale of 1 ('low') to 6 ('high'). The scores depend on the level of performance in a given year assessed against the criteria, rather than on changes in performance compared with the previous year. The ratings process involves two key phases. In the benchmarking phase a small, representative sample of countries drawn from all regions is rated; in the second phase, staff rate the remaining countries using benchmark countries' scores as guideposts (see World Bank, 2014, for more details).

To these assessments of public policies, we add several other explanatory variables. First, we control for the level of initial development in order to check if there is a certain 'path-dependence' in growth processes. Second, we consider the impact on growth exercised by growth domestic investments. We also account for the fact that, starting with 1970s, an abundant string of literature explores the significant (although still controversial) relationship between the natural resource abundance and economic growth (Leite and Weidmann, 2009; Gylfason and Zoega, 2006; Bond and Malik, 2009; Asiedu and Lien, 2011; Murphy and Hall, 2011). Third, we take into account the role played by higher education in the formation of human capital, building technological capabilities and supporting the emergence of knowledge-based growth mechanisms (Wolf, 2002; Barro, 2001; Lin, 2004; Bloom et al., 2006; Gyimah-Brempong et al.,2006; Kruss et al., 2015). Fourth, we consider the possible existence of a 'virtuous circle', where growth and democratic capital reinforces each other as well as the various constraints induced by democratic institutions in the design of public policies (Przeworski and Limongi, 1993; Alesina et al., 1996; Feng, 1997; Jong-A-Pin, 2009; Youniset al., 2008; Persson and Tabellini, 2009). Finally, we refer to the role played by culture (as well as by the past colonial experience in sustaining a specific growth trajectory, as are these captured by the use of English language (Price, 2003; Austin, 2008; Williamson and Mathers, 2010).

All the dependent and explanatory variables are averaged on a time span between 2005 and 2014 , in order to eliminate the impact of short and medium business cycle, and a cross-section analysis is carried out.

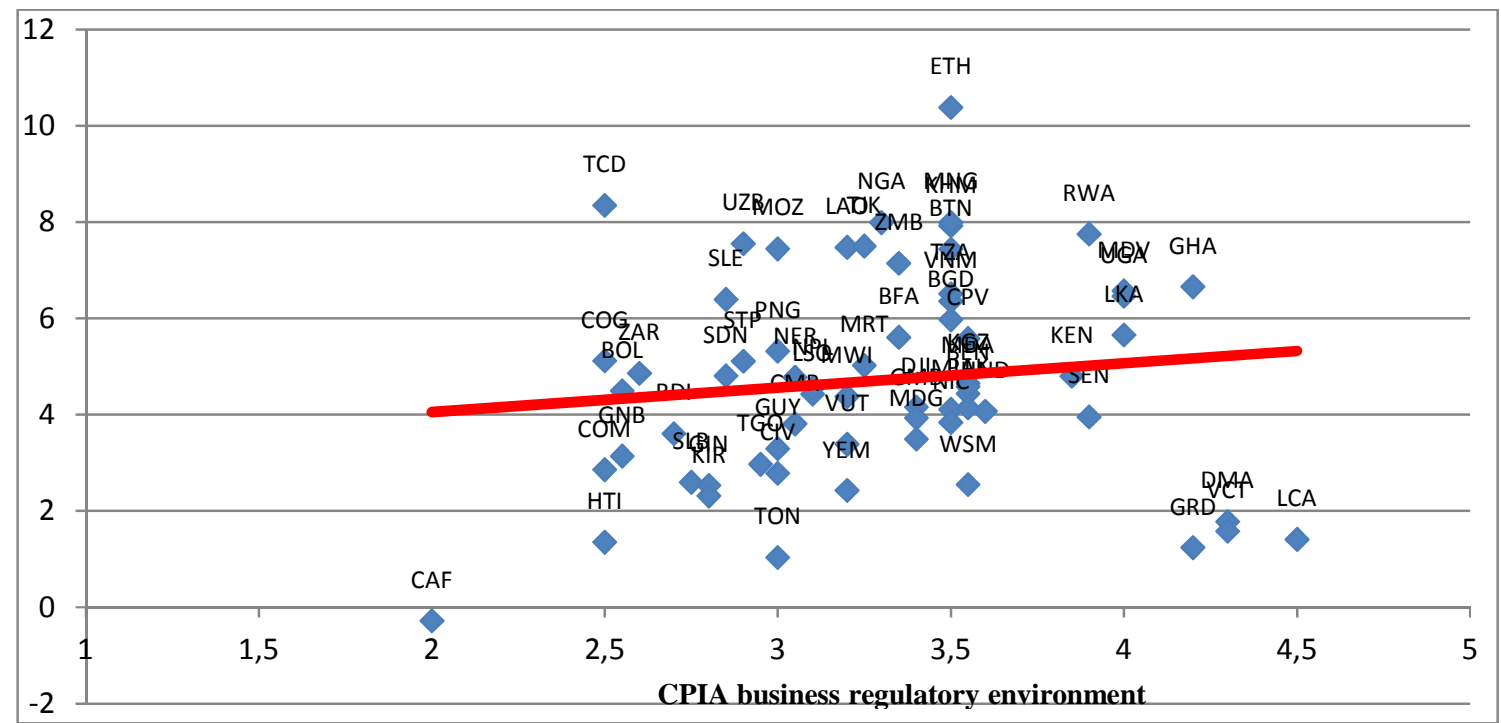

Figure 1. Business regulations and growth (cross-country evidences) 


\section{RESULTS AND COMMENTS}

\section{Baseline results}

The baseline results are report in Table 1. Here we report the unconditional, conditional and standardized (i.e. coefficients that arise if both the response and the regressors are normalized to mean zero and variance one) coefficients. Column 1 reflects the relative importance of the considered variables in explaining growth through the posterior inclusion probabilities (PIPs)-i.e. the sum of posterior model probabilities for all models where a covariate was included. Column 2 displays the coefficients averaged over all models, while Column 3 shows posterior standard deviations.

Table 1. Growth and business regulatory environment (baseline results)

\begin{tabular}{|c|c|c|c|c|c|c|c|c|}
\hline \multirow{3}{*}{ Variables } & \multicolumn{4}{|c|}{ Unconditional coefficients } & \multicolumn{2}{|c|}{$\begin{array}{l}\text { Conditional } \\
\text { coefficients }\end{array}$} & \multicolumn{2}{|c|}{$\begin{array}{c}\text { Standardized } \\
\text { coefficients }\end{array}$} \\
\hline & $\begin{array}{l}\text { Posterior } \\
\text { Inclusion } \\
\text { Probabili } \\
\quad \text { ties }\end{array}$ & $\begin{array}{l}\text { Post } \\
\text { Mean }\end{array}$ & $\begin{array}{c}\text { Post } \\
\text { SD }\end{array}$ & $\begin{array}{c}\text { Posterior } \\
\text { probability } \\
\text { of a positive } \\
\text { coefficient } \\
\text { expected } \\
\text { value } \\
\text { conditional } \\
\text { on inclusion }\end{array}$ & $\begin{array}{c}\text { Post } \\
\text { Mean }\end{array}$ & $\begin{array}{c}\text { Post } \\
\text { SD }\end{array}$ & $\begin{array}{c}\text { Post } \\
\text { Mean }\end{array}$ & $\begin{array}{c}\text { Post } \\
\text { SD }\end{array}$ \\
\hline & (1) & $(2)$ & (3) & (4) & $(5)$ & $(6)$ & $(7)$ & (8) \\
\hline CPIA trade & 0.859 & -1.355 & 0.766 & 0.000 & -1.578 & 0.576 & -0.300 & 0.169 \\
\hline Natural Rents & 0.589 & 0.026 & 0.027 & 1.000 & 0.044 & 0.020 & 0.163 & 0.169 \\
\hline $\begin{array}{l}\text { CPIA transparency, } \\
\text { accountability, and } \\
\text { corruption in the } \\
\text { public sector } \\
\text { environment }\end{array}$ & 0.547 & -0.639 & 0.714 & 0.000 & -1.167 & 0.562 & -0.189 & 0.212 \\
\hline $\begin{array}{l}\text { CPIA business } \\
\text { regulatory } \\
\text { environment }\end{array}$ & 0.534 & 0.891 & 1.028 & 0.998 & 1.670 & 0.825 & 0.214 & 0.247 \\
\hline $\begin{array}{l}\text { CPIA equity of public } \\
\text { resource use }\end{array}$ & 0.524 & 0.856 & 1.000 & 1.000 & 1.634 & 0.798 & 0.208 & 0.243 \\
\hline $\begin{array}{l}\text { CPIA property rights } \\
\text { and rule-based } \\
\text { governance }\end{array}$ & 0.512 & -0.870 & 1.071 & 0.003 & -1.701 & 0.910 & -0.232 & 0.286 \\
\hline $\begin{array}{l}\text { CPIA debt policy } \\
\text { rating }\end{array}$ & 0.476 & 0.454 & 0.584 & 1.000 & 0.955 & 0.488 & 0.150 & 0.193 \\
\hline $\begin{array}{l}\text { English language (as } \\
\text { first or second } \\
\text { language) }\end{array}$ & 0.468 & -0.537 & 0.702 & 0.000 & -1.147 & 0.594 & -0.104 & 0.136 \\
\hline $\begin{array}{l}\text { GNI per capita, PPP } \\
\text { (constant } 2011 \\
\text { international \$) (log- } \\
\text { levels for 2004) }\end{array}$ & 0.465 & -0.825 & 1.094 & 0.000 & -1.773 & 0.945 & -0.121 & 0.160 \\
\hline $\begin{array}{l}\text { CPIA building human } \\
\text { resources rating }\end{array}$ & 0.391 & 0.493 & 0.767 & 1.000 & 1.261 & 0.731 & 0.126 & 0.196 \\
\hline $\begin{array}{l}\text { CPIA social protection } \\
\text { and labour }\end{array}$ & 0.291 & 0.347 & 0.700 & 0.999 & 1.191 & 0.825 & 0.073 & 0.148 \\
\hline $\begin{array}{l}\text { CPIA quality of } \\
\text { budgetary and } \\
\text { financial management }\end{array}$ & 0.259 & 0.284 & 0.639 & 0.998 & 1.100 & 0.828 & 0.065 & 0.147 \\
\hline $\begin{array}{l}\text { CPIA quality of public } \\
\text { administration }\end{array}$ & 0.217 & 0.232 & 0.640 & 0.964 & 1.068 & 0.996 & 0.048 & 0.133 \\
\hline
\end{tabular}




\begin{tabular}{|c|c|c|c|c|c|c|c|c|}
\hline $\begin{array}{l}\text { Gross capital } \\
\text { formation ( } \% \text { of GDP) }\end{array}$ & 0.212 & 0.007 & 0.017 & 1.000 & 0.031 & 0.026 & 0.029 & 0.077 \\
\hline Gross enrolment ratio & 0.209 & 0.005 & 0.016 & 0.943 & 0.026 & 0.026 & 0.028 & 0.083 \\
\hline $\begin{array}{l}\text { Political Stability and } \\
\text { Absence of } \\
\text { Violence/Terrorism }\end{array}$ & 0.205 & 0.076 & 0.262 & 0.849 & 0.372 & 0.475 & 0.033 & 0.113 \\
\hline CPIA gender equality & 0.195 & 0.101 & 0.311 & 0.962 & 0.518 & 0.531 & 0.029 & 0.089 \\
\hline CPIA financial sector & 0.187 & -0.141 & 0.463 & 0.062 & -0.756 & 0.824 & -0.029 & 0.096 \\
\hline CPIA fiscal policy & 0.144 & 0.048 & 0.275 & 0.831 & 0.336 & 0.656 & 0.012 & 0.070 \\
\hline $\begin{array}{l}\text { CPIA macroeconomic } \\
\text { management }\end{array}$ & 0.141 & 0.035 & 0.268 & 0.755 & 0.249 & 0.675 & 0.008 & 0.062 \\
\hline $\begin{array}{l}\text { CPIA efficiency of } \\
\text { revenue mobilization }\end{array}$ & 0.132 & 0.042 & 0.296 & 0.826 & 0.320 & 0.757 & 0.009 & 0.064 \\
\hline $\begin{array}{l}\text { CPIA policy and } \\
\text { institutions for } \\
\text { environmental } \\
\text { sustainability }\end{array}$ & 0.125 & 0.021 & 0.271 & 0.710 & 0.170 & 0.750 & 0.005 & 0.062 \\
\hline Model space $\left(2^{\wedge} \mathrm{K}\right)$ & 4194304 & & & & & & & \\
\hline$\%$ Top models & $48 \%$ & & & & & & & \\
\hline $\begin{array}{l}\text { Correlation between } \\
\text { iteration counts and } \\
\text { analytical PMPs for } \\
\text { the } 10000 \text { best } \\
\text { models }\end{array}$ & 0.997 & & & & & & & \\
\hline $\begin{array}{l}\text { The average number } \\
\text { of included regressors }\end{array}$ & 7.680 & & & & & & & \\
\hline
\end{tabular}

Notes: Parameter prior:" g"; Parameter prior value: UIC; Model prior choice: "Uniform

Several conclusions can be draw based on such results. First, it appears clearly that the quality of business regulations positively supports economic growth in a robust manner, regardless of how the coefficients are specified: $53.4 \%$ of posterior model mass rests on models that include CPIA business regulatory environment. The extent to which the legal, regulatory and policy environments help or hinder private businesses in investing, creating jobs, and becoming more productive acts like a strong pro-growth factor. A comparison between unconditional and, respectively, conditional estimates of the corresponding averaged coefficient (Column 5) provides further details about the relatively importance of business regulatory environment comparing with other determinants of growth. Since the computation of the unconditional coefficients often includes models where these coefficients are zero, the conditional level appears to be almost two times larger in the case of this explanatory variable. However, only in the case of standardized coefficients (Column 7) the data displays the same order of magnitude, allowing for more direct comparisons. For such coefficients, the inference of the importance of the considered explanatory variables leads to the conclusion that the extent to which the policy framework fosters trade, natural resources rents, transparency, accountability, and control of corruption in the public sector environment, business regulatory environment, equity of public resource use and, respectively, property rights and rule-based governance - with the largest levels and posterior inclusion probabilities superior to 0.5 - exercises the most important influences on growth. From these variables, the CPIA estimate of business regulations appears to exercise the third largest impact after trade policies and rule-based governance. Nevertheless, it can be noticed that trade, accountability and property rights and rule-based governance variables display ambiguous negative signs (as Column 4, reporting the posterior probability of a positive coefficient, shows it). Several factors can explain such outcome: the existence of a 'path-dependence' in growth processes; the adoption by the considered countries of an 'extensive' model of growth with a lower weight of high-technology sectors (as, for instance, suggested by the importance of natural rents as a growth determinant); the dependence to international markets' prices (such as the 
prices of 'strategic' raw materials) and, broadly, the countries' vulnerability to exogenous shocks; the shock waves of the recent financial and real turmoil; the legacy of a history of poor institutional quality or the social, cultural and behavioral environment.

Supplementary, Harstad and Svensson (2011) provide an interesting argument in explaining the negative sign obtained for CPIA transparency, accountability, and corruption in the public sector rating. According to their model, when the level of development is low, companies are more inclined to bend the rule through bribery. Meanwhile, they tend to switch to lobbying when the level of development reaches a certain threshold. Hence, the liberalization of the regulatory framework is more likely to generate positive effects over time and their results suggest that the penalty of corruption should be lower in poor countries.

Second, as displayed in Figure 2, the prior model size distribution implies a symmetric distribution around $\mathrm{K} / 2=11$. Nevertheless, updating it with data, yield to a posterior that puts more importance on parsimonious models. More exactly, with $2 \mathrm{~K}$ possible variable combinations, a uniform model prior means a common prior model probability and a prior expected model size of $\mathrm{K} / 2$. Likewise, the uniform model prior puts more mass on intermediate model sizes e.g. expecting a model size of while the posterior expected model size (i.e. the average number of included regressors) is equal to 7.68.

Also, Figure 2 presents the best 2,000 models encountered ordered by their analytical posterior model probabilities (PMPs) (the red line), and plots their MCMC iteration counts (the blue line). At a level of 0.997, the correlation between iteration counts and analytical PMPs indicates a high degree of convergence.
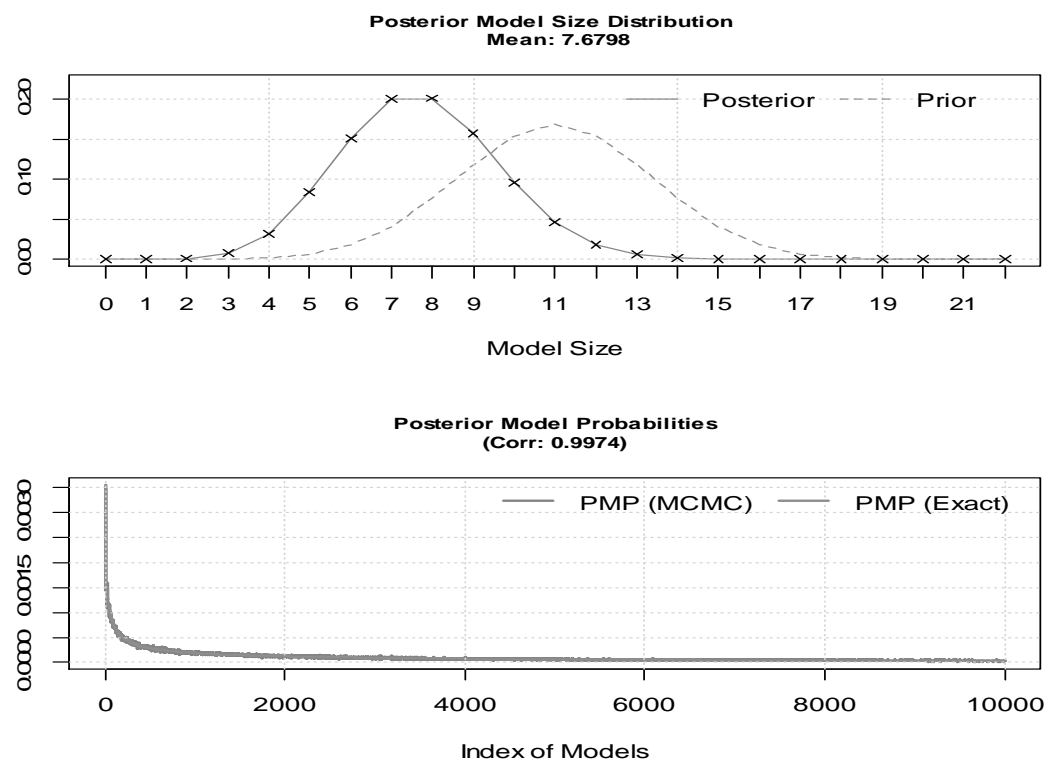

Figure 2. Posterior model size distribution and probabilities (UIC/uniform priors)

Third, Figure 3 displays the marginal densities of posterior coefficient distribution for CPIA business regulatory environment, which is a model-weighted mixture of posterior densities for each model. The coefficient appears to be neatly above zero, but somewhat skewed. 


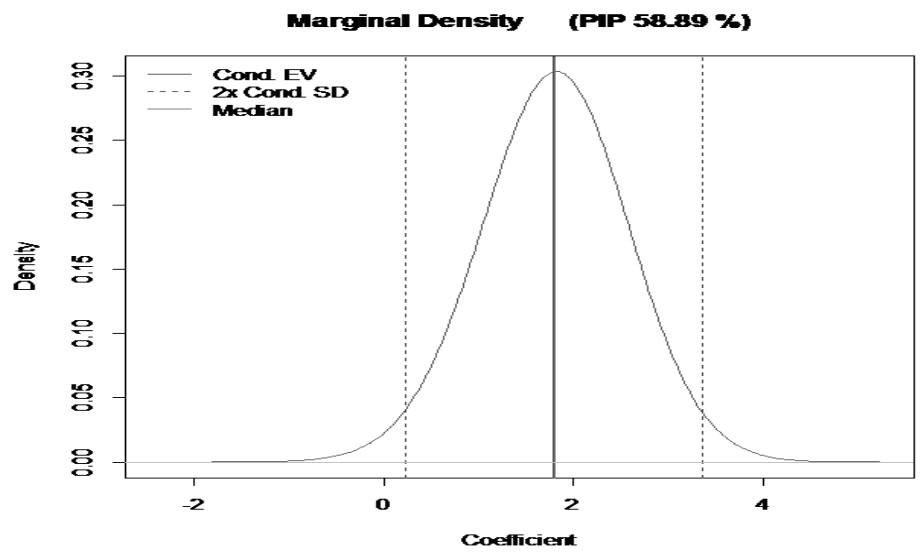

Figure 3. Marginal densities of posterior coefficient distribution for CPIA business regulatory environment

Overall, it appears that the uniform model prior assumption provides some evidences for the positive impact of business regulatory environment quality on growth.

However, Eicher et al. (2011) show that the PIPs for some standard growth determinants may vary depending on the prior structure. For instance, when g takes the 'hyper-g' prior distribution (as in Liang et al., 2008), with the default hyper-parameter a set such that the prior expected shrinkage factor conforms to 'BRIC', the overall picture changes as in Table 2.

Table 2. Growth and business regulatory environment (Hyper BRIC parameter prior)

\begin{tabular}{|l|c|c|c|c|}
\hline & $\begin{array}{c}\text { Posterior } \\
\text { Inclusion } \\
\text { Probabilities }\end{array}$ & $\begin{array}{c}\text { Post } \\
\text { Mean }\end{array}$ & $\begin{array}{c}\text { Post } \\
\text { SD }\end{array}$ & $\begin{array}{c}\text { Posterior probability } \\
\text { of a positive } \\
\text { coefficient } \\
\text { expected value } \\
\text { conditional on } \\
\text { inclusion }\end{array}$ \\
\hline CPIA trade & $\mathbf{( 1 )}$ & $\mathbf{( 2 )}$ & $\mathbf{( 3 )}$ & \multicolumn{2}{|c|}{ (4) } \\
\hline CPIA business regulatory environment & 0.913 & -1.217 & 0.632 & 0.000 \\
\hline $\begin{array}{l}\text { CPIA property rights and rule-based } \\
\text { governance }\end{array}$ & 0.712 & 0.982 & 0.913 & 0.999 \\
\hline Natural Rents & 0.681 & -0.982 & 0.997 & 0.001 \\
\hline $\begin{array}{l}\text { CPIA transparency, accountability, and } \\
\text { corruption in the public sector }\end{array}$ & 0.669 & 0.021 & 0.021 & 1.000 \\
\hline $\begin{array}{l}\text { GNI per capita, PPP (constant 2011 } \\
\text { international \$) (log-levels for 2004) }\end{array}$ & 0.660 & -0.591 & 0.609 & 0.000 \\
\hline $\begin{array}{l}\text { English language (as first or second } \\
\text { language) }\end{array}$ & 0.644 & -0.898 & 0.965 & 0.000 \\
\hline CPIA debt policy rating & 0.624 & -0.543 & 0.610 & 0.000 \\
\hline CPIA equity of public resource use & 0.603 & 0.421 & 0.498 & 1.000 \\
\hline CPIA building human resources rating & 0.564 & 0.591 & 0.783 & 0.998 \\
\hline $\begin{array}{l}\text { Political Stability and Absence of } \\
\text { Violence/Terrorism }\end{array}$ & 0.490 & 0.393 & 0.635 & 0.000 \\
\hline CPIA social protection and labour & 0.465 & 0.177 & 0.343 & 0.920 \\
\hline CPIA quality of public administration & 0.452 & 0.347 & 0.643 & 0.969 \\
\hline Gross enrolment ratio & 0.423 & 0.330 & 0.706 & 0.928 \\
\hline $\begin{array}{l}\text { CPIA quality of budgetary and financial } \\
\text { management }\end{array}$ & 0.413 & 0.008 & 0.018 & 0.985 \\
\hline
\end{tabular}




\begin{tabular}{|c|c|c|c|c|}
\hline Gross capital formation ( $\%$ of GDP) & 0.397 & 0.008 & 0.018 & 0.999 \\
\hline CPIA financial sector & 0.371 & -0.153 & 0.487 & 0.117 \\
\hline CPIA gender equality & 0.368 & 0.099 & 0.344 & 0.878 \\
\hline CPIA macroeconomic management & 0.337 & 0.006 & 0.397 & 0.533 \\
\hline CPIA fiscal policy & 0.336 & 0.049 & 0.388 & 0.690 \\
\hline CPIA efficiency of revenue mobilization & 0.332 & 0.068 & 0.412 & 0.802 \\
\hline $\begin{array}{l}\text { CPIA policy and institutions for } \\
\text { environmental sustainability }\end{array}$ & 0.321 & 0.005 & 0.393 & 0.529 \\
\hline Model space $\left(2^{\wedge} \mathrm{K}\right)$ & 4194304 & & & \\
\hline \multicolumn{5}{|l|}{ Shrinkage-Stats } \\
\hline Average & 0.780 & & & \\
\hline Standard deviation & 0.110 & & & \\
\hline \% Top models & $12.8 \%$ & & & \\
\hline $\begin{array}{l}\text { Correlation between iteration counts } \\
\text { and analytical PMPs for } \\
\text { the } 10000 \text { best models }\end{array}$ & 0.963 & & & \\
\hline
\end{tabular}

Notes: Parameter prior:" hyper"; Parameter prior value: BRIC; Model prior choice: "Uniform

Here, the corresponding PIP for CPIA business regulatory environment variable substantially increases to 0.71 , while the sign remains positive. For the other variables, GNI per capita as a measure of the initial level of development, a cultural variable such as English language (as first or second language), CPIA debt policy rating, and CPIA equity of public resource use largely gains in explanatory power, while trade, accountability and property rights and rule-based governance variables continue to display the same 'wrong' impact.
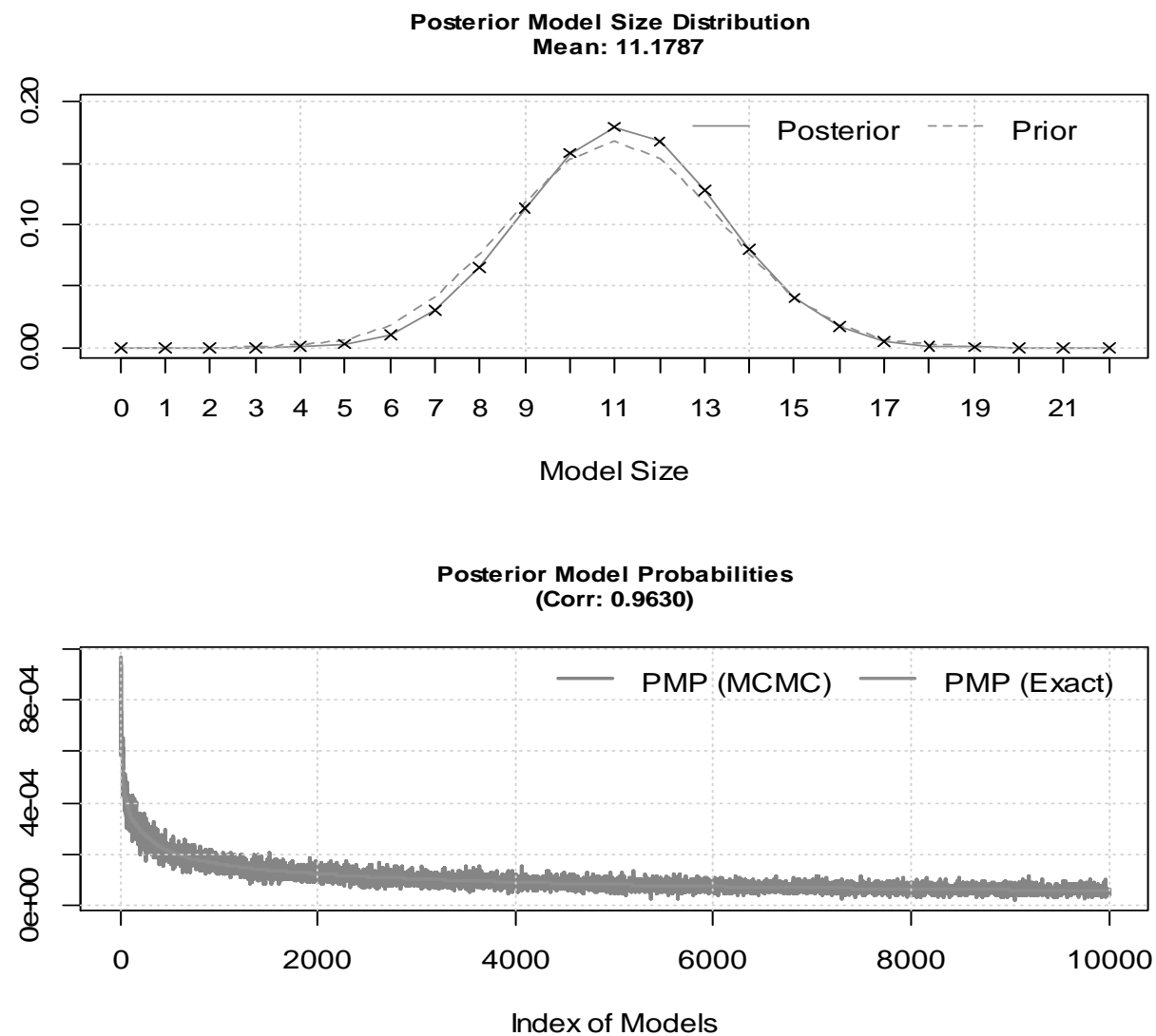
Figure 4. Posterior model size distribution and probabilities (Hyper-BRIC/uniform priors)

The upper chart of Figure 4 shows that posterior model size distribution remains very close to the model prior. Meanwhile, the lower part of this Figure 4 displays the discordance between iteration count frequencies and analytical PMPs.

The posterior expected shrinkage is 0.78 , with rather tight standard deviation bounds. Figure 5 confirms that posterior shrinkage is tightly concentrated above 0.70 .

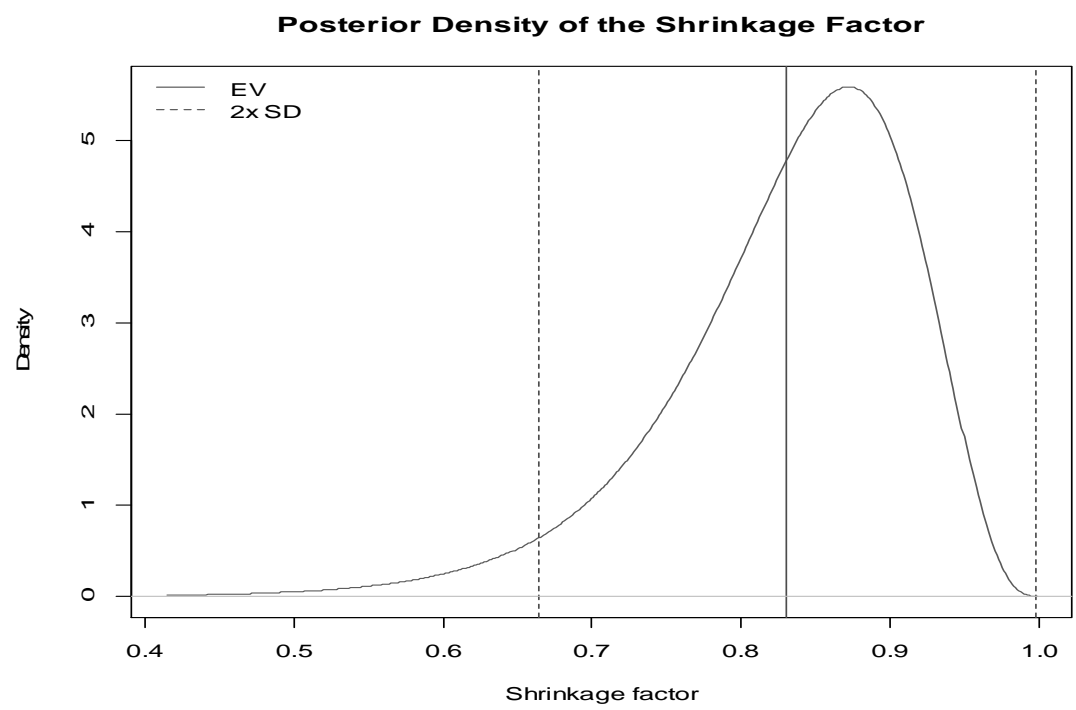

Figure 5. Posterior density of the shrinkage factor (Hyper-BRIC/uniform priors)

We further investigate the sensitivity of our results to the selection of priors' structures. Table 3 reports the results of such analysis for other nine different settings.

Table 3. The impact of business regulatory environment on growth (various priors)

\begin{tabular}{|l|c|c|c|c|c|c|c|c|c|c|c|}
\hline $\begin{array}{l}\text { Posterior } \\
\text { inclusion } \\
\text { probability }\end{array}$ & 0.534 & 0.712 & 0.723 & 0.724 & 0.519 & 0.517 & 0.710 & 0.733 & 0.721 & 0.699 & 0.711 \\
\hline Posterior mean & 0.891 & 0.982 & 1.011 & 1.013 & 0.864 & 0.863 & 0.979 & 1.065 & 1.046 & 1.015 & 0.980 \\
\hline $\begin{array}{l}\text { Posterior } \\
\text { standard } \\
\text { deviation }\end{array}$ & 1.028 & 0.913 & 0.920 & 0.921 & 1.023 & 1.023 & 0.913 & 0.932 & 0.934 & 0.937 & 0.913 \\
\hline Parameter prior & $\mathrm{g}$ & hyper & $\mathrm{g}$ & $\mathrm{g}$ & $\mathrm{g}$ & $\mathrm{g}$ & hyper & hyper & hyper & hyper & hyper \\
\hline $\begin{array}{l}\text { Parameter prior } \\
\text { value }\end{array}$ & UIP & BRIC & EBL & EBL & HQ & HQ & UIP & UIP & UIP & BRIC & BRIC \\
\hline $\begin{array}{l}\text { Model prior } \\
\text { choice }\end{array}$ & Jniform & Jniform & Fixed & Jniform & Jniform & Fixed & Fixed & Random & Jniform Random Fixed \\
\hline
\end{tabular}

Notes: The results for the other variables not reported here. Different from baseline results, a reversiblejump sampler is involved (Madigan and York, 1995).This sampler either draws a candidate by the birthdeath method with $50 \%$ probability. In the other case (chosen with $50 \%$ probability) a 'swap' is proposed, i.e. the candidate model $M_{j}$ randomly drops one covariate with respect to $M_{i}$ and randomly adds one chosen at random from the potential covariates that were not included in model $M_{i}$.

With these settings, the corresponding PIP for business regulations varies between 0.52 and 0.72 , while posterior mean remains positive in a stable manner (around $99.8 \%-99.9 \%$ of the cases 
depending on the prior structure). The highest PIPs are obtained when the 'hyper-g' prior distribution (as in Liang et al., 2008) is involved jointly with 'fixed' or 'random' settings for model prior choice. Lowest PIPs occur when the hyper-parameter on Zellner's g-prior for the regression coefficients mimics the Hannan-Quinn criterion (cf. Fernandez et al., 2001: 395) with 'uniform' and 'fixed' model prior choice. For all estimates, the values of posterior means are greater than the uniform prior.

\section{Endogeneity issues}

If the design of public institutions and the implementation of public policies are chosen in a completely exogenous manner by the members of political structures or, alternatively, if the institutions and policies are viewed as being 'fixed' (at least on 'short-run') then the potential causality flows from these institutions and policies to growth and no endogeneity issues should be expected. Nonetheless, if rapid growth processes are susceptible to modify the institutional framework and to change the public authorities' utility function, then reverse causality from growth to institutions and policies might occur. Indeed, literature provides some evidences of such impact of growth. For instance, Alonso and Garcimartín (2013) find that development level determines institutional quality: higher the former, higher the latter. Two main arguments might account for such positive impact of development, which emerges both through supply as well as demand side. First, a higher level of development generates more resources available for the construction of better institutions. Second, there is an increased demand for a higher institutional quality with sustainable development evolutions. Islam and Montenegro (2002), Glaeser et al. (2004), and Rigobon and Rodrik (2005) obtain similar results. In Glaeser et al. (2004:287) words: "From the beginning, the growth and institutions research recognized that growth may itself lead to better institutions".

Thus, we need to address this potential endogeneity within BMA model. In order to perform this check, we follow the method proposed by Karl and Lenkoski (2012) and implemented in Karl et al. (2015) to perform model averaging in two-stage linear regression systems subject to endogeneity. This method is built on a Gibbs sampler for the instrumental variables framework, discussed in Rossi et al. (2006) and it is based on the notion of a conditional Bayes factor (CBF). It compares two models in a nested hierarchical system, conditional on parameters not influenced by the models under consideration. Karl and Lenkoski (2012) show that, by nesting model moves inside the Gibbs sampler, model comparison can be performed, via conditional Bayes factors, leading to straightforward calculations, without evidences of mixing difficulties. The considered IVBMA models the entire system, jointly with important improvement in computational efficiency. Table 4 reports the results.

Table 4. Growth and business regulatory environment (IVBMA results)

\begin{tabular}{|l|r|r|r|r|r|}
\hline \multicolumn{1}{|c|}{ Variable } & $\begin{array}{c}\text { Posterior } \\
\text { Inclusion } \\
\text { Probabilities }\end{array}$ & $\begin{array}{c}\text { Posterior } \\
\text { Mean }\end{array}$ & Lower & Median & Upper \\
\hline Natural Rents & 0.784 & 0.041 & 0 & 0.046 & 0.085 \\
\hline $\begin{array}{l}\text { CPIA transparency, accountability, and } \\
\text { corruption in the public sector }\end{array}$ & 0.768 & -0.718 & -1.855 & -0.752 & 0.009 \\
\hline CPIA equity of public resource use & 0.74 & 0.811 & 0 & 0.799 & 2.249 \\
\hline CPIA trade & 0.686 & -0.679 & -1.794 & -0.748 & 0 \\
\hline CPIA building human resources rating & 0.674 & 0.591 & -0.243 & 0.51 & 1.9 \\
\hline $\begin{array}{l}\text { GNI per capita, PPP (constant 2011 } \\
\text { international \$) (levels for 2004) }\end{array}$ & 0.651 & -0.329 & -1.591 & -0.02 & 0.684 \\
\hline CPIA business regulatory environment & 0.604 & 0.089 & -1.375 & 0 & 1.574 \\
\hline
\end{tabular}




\begin{tabular}{|l|r|r|r|r|r|}
\hline CPIA social protection and labour & 0.53 & 0.376 & -0.304 & 0 & 1.75 \\
\hline $\begin{array}{l}\text { CPIA property rights and rule-based } \\
\text { governance }\end{array}$ & 0.528 & -0.285 & -1.651 & 0 & 0.591 \\
\hline $\begin{array}{l}\text { CPIA quality of budgetary and financial } \\
\text { management }\end{array}$ & 0.504 & 0.286 & -0.596 & 0 & 1.632 \\
\hline CPIA debt policy rating & 0.492 & 0.313 & -0.052 & 0 & 1.35 \\
\hline CPIA efficiency of revenue mobilization & 0.461 & 0.051 & -0.832 & 0 & 1.046 \\
\hline $\begin{array}{l}\text { English language (as first or second } \\
\text { language) }\end{array}$ & 0.459 & -0.33 & -1.561 & 0 & 0.149 \\
\hline CPIA fiscal policy & 0.441 & 0.205 & -0.355 & 0 & 1.319 \\
\hline CPIA quality of public administration & 0.439 & 0.288 & -0.487 & 0 & 1.764 \\
\hline CPIA macroeconomic management & 0.404 & 0.079 & -0.66 & 0 & 1.002 \\
\hline $\begin{array}{l}\text { CPIA policy and institutions for } \\
\text { environmental sustainability }\end{array}$ & 0.382 & 0.036 & -0.792 & 0 & 0.953 \\
\hline CPIA gender equality & 0.348 & 0.158 & -0.244 & 0 & 1.145 \\
\hline $\begin{array}{l}\text { Political Stability and Absence of } \\
\text { Violence/Terrorism }\end{array}$ & 0.283 & -0.01 & -0.45 & 0 & 0.375 \\
\hline CPIA financial sector & 0.248 & -0.066 & -1.026 & 0 & 0.492 \\
\hline Gross enrolment ratio & 0.084 & 0 & -0.006 & 0 & 0.016 \\
\hline Sargan test(probability) & 0.760 & & & \\
\hline
\end{tabular}

Notes: Instruments for business regulatory environment: two regional dummies for Africa and Asia and Foreign Direct Investments (net inflows; \% GDP)

We argue that there might be some regional trends in setting the regulatory architecture and, hence, we use, as instruments, two regional dummies for Africa and Asia. In addition, there is an extensive stream of literature dealing with the inter-connectivity between Foreign Direct Investments and the quality of regulatory environment (Alesina and Dollar, 2000; Globerman and Shapiro, 2002; Busse and Groizard, 2008; Morris and Aziz, 2011; Munemo, 2014; Adams and Opoku, 2015). The argument is a quite straightforward one: if the foreign companies are largely present in the host economy, these will be able to put pressure on the implementation process of pro-business policies and the implementation of a sound, transparent and stable business environment.

With this procedure, the estimated influence of business regulatory environment variable on growth remains important and positive with a PIP of 0.60 (although the level of the coefficient substantially declines around ten times, once endogeneity is accounted for). In respect to other variables, the picture remain largely unchanged with natural rents, CPIA transparency, accountability and corruption in the public sector, CPIA equity of public resource use, CPIA trade and GNI per capita among the most important explanatories. However, three other new variables become relevant: CPIA building human resources rating, CPIA social protection and labor and, respectively, CPIA quality of budgetary and financial management, while, for English language, the corresponding PIP becomes lower than 0.5. The instrumentalisation does not correct for the ambiguous impact of trade regulations, accountability and rule-based governance.

Additionally, it is worth to note that, in this framework, we also checked for a potential nonlinear transmission of the impact exercised by business regulations on growth. The results (not reported here, but available at request) do not indicate that a higher quality level of business supporting policies is detrimental to growth. We find virtually a zero PIP for the squared level of the CPIA variable, while the inclusion of the non-linear effect leads to a decrease in the corresponding PIP for level to 0.41 . 


\section{Sample issues}

Several examples from literature suggest that the mechanisms of growth are far from homogenous, even for low-income countries. For instance, Masanjala and Papageorgiou (2008) argue that key engines of growth in Africa are substantially different from those in the rest of the world (with mining, primary exports and initial primary education exerting a differential effect). Thus, a deeper assessment of the results' robustness requires a more detailed analysis of the considered sample.

Glaeser et al. (2004: 286) suggest an interesting split-of criterion by noticing that: "although nearly all poor countries in 1960 were dictatorships, some of them have managed to get out of poverty, while others stayed poor. This kind of evidence is at least suggestive that it is the choices made by the dictators, rather than the constraints on them, that have allowed some poor countries to emerge from poverty". In accordance with this line of reasoning, 'good' policies can compensate (at least to a certain extent and up to a certain level of development) for 'bad' institutions. Of course, this argument does not entail that 'democracy does not matter for economic growth'. Rather, it is related to the view that "countries that emerge from poverty accumulate human and physical capital under dictatorships, and then, once they become richer, are increasingly likely to improve their institutions" (Glaeser et al., 2004: 298). Hence, as we already mentioned, there might be a growth-policies-institutions nexus. Accounting for this, and aiming to evaluate the importance of the potential substitution effects between policies and institutions, we consider a sub-sample of countries with lower levels of political and individual freedoms.

With this purpose, we involve the World Governance Indicators (WGI) project measure of the democratic status -"Voice and accountability" -, which seeks to capture perceptions of the extent to which a country's citizens are able to participate in selecting their government, as well as freedom of expression, freedom of association, and a free media (Kaufmann et al., 2011). We exclude, from our dataset, the countries with positive averages values of this indicator for the analyzed time span and we focus exclusively on the others in the IVBMA framework. Table 5 reports the results.

Table 5. Growth and business regulatory environment (IVBMA results)-reduced sample

\begin{tabular}{|l|r|r|r|r|r|}
\hline \multicolumn{1}{|c|}{ Variable } & $\begin{array}{c}\text { Posterior } \\
\text { Inclusion } \\
\text { Probabilities }\end{array}$ & $\begin{array}{c}\text { Posterior } \\
\text { Mean }\end{array}$ & Lower & Median & Upper \\
\hline CPIA trade & 1 & -1.341 & -2.163 & -1.359 & -0.461 \\
\hline CPIA building human resources rating & 0.877 & 0.894 & -0.178 & 0.939 & 2.214 \\
\hline $\begin{array}{l}\text { English language (as first or second } \\
\text { language) }\end{array}$ & 0.657 & -0.341 & -1.51 & -0.086 & 0.501 \\
\hline CPIA business regulatory environment & 0.634 & 0.483 & -0.552 & 0.141 & 2.124 \\
\hline CPIA financial sector & 0.626 & -0.071 & -1.263 & 0 & 0.96 \\
\hline CPIA fiscal policy & 0.593 & 0.453 & -0.255 & 0.232 & 1.647 \\
\hline CPIA equity of public resource use & 0.553 & 0.413 & -0.259 & 0 & 1.733 \\
\hline $\begin{array}{l}\text { CPIA transparency, accountability, and } \\
\text { corruption in the public sector }\end{array}$ & 0.542 & -0.266 & -1.329 & 0 & 0.398 \\
\hline $\begin{array}{l}\text { CPIA property rights and rule-based } \\
\text { governance }\end{array}$ & 0.508 & 0.122 & -0.831 & 0 & 1.272 \\
\hline CPIA macroeconomic management & 0.474 & 0.204 & -0.497 & 0 & 1.281 \\
\hline $\begin{array}{l}\text { CPIA quality of budgetary and financial } \\
\text { management }\end{array}$ & 0.469 & 0.225 & -0.474 & 0 & 1.427 \\
\hline CPIA social protection and labor & 0.45 & 0.27 & -0.505 & 0 & 1.723 \\
\hline
\end{tabular}




\begin{tabular}{|l|r|r|r|r|r|}
\hline $\begin{array}{l}\text { CPIA policy and institutions for } \\
\text { environmental sustainability }\end{array}$ & 0.378 & 0.012 & -0.993 & 0 \\
\hline CPIA quality of public administration & 0.34 & 0.023 & -1.005 & 0 & 1.057 \\
\hline $\begin{array}{l}\text { GNI per capita, PPP (constant 2011 } \\
\text { international \$) (levels for 2004) }\end{array}$ & 0.326 & 0.074 & -0.636 & 0 & 0.973 \\
\hline CPIA debt policy rating & 0.311 & 0.146 & -0.145 & 0 & 1.116 \\
\hline CPIA efficiency of revenue mobilization & 0.261 & -0.008 & -0.703 & 0 & 0.73 \\
\hline CPIA gender equality & 0.216 & 0.005 & -0.503 & 0 & 0.541 \\
\hline $\begin{array}{l}\text { Political Stability and Absence of } \\
\text { Violence/Terrorism }\end{array}$ & 0.171 & 0.034 & -0.233 & 0 & 0.637 \\
\hline Natural Rents & 0.128 & 0.005 & 0 & 0 & 0.052 \\
\hline Gross enrolment ratio & 0.061 & 0 & -0.009 & 0 & 0.006 \\
\hline Gross capital formation (\% of GDP) & 0 & 0 & 0 & 0 & 0 \\
\hline Sargan test(probability) & 0.436 & & & & 0 \\
\hline
\end{tabular}

Notes: Same instruments as in Table 4. Excluded countries (with positive average values for 'Voice and Accountability' variable) are: Benin, Cabo Verde, Dominica, Ghana, Grenada, Guyana, Kiribati, Mali, Mongolia, Papua New Guinea, Samoa, Sao Tome and Principe, Solomon Islands, St. Lucia, St. Vincent and the Grenadines, Tonga, and Vanuatu.

The relative importance of the business regulatory environment slightly increases in terms of PIPs, but is around six times larger in terms of posterior mean. For the other variables, the most striking increase in explanatory power is the one corresponding to the national policies and public and private sector service delivery that affects the access to and quality of health and education services [although a variable for higher education such 'school enrolment, tertiary (\% gross)' does not appear to play any role in explaining growth]. Since such policies affect directly and extensively the human capital, it appears that the public policies supporting business supports growth together with the enhancement of human and social capital, even in countries with lower institutional quality. Interesting enough, in this sub-sample, the CPIA variable reflecting private economic activity is facilitated by an effective legal system and rule-based governance structure, in which property and contract rights are reliably respected and enforced; and it appears with a PIP greater than 0.5 and with a "right" positive sign of posterior mean. Less democratic countries seem to be able to benefit from relatively high rates of growth, under the condition of promoting corresponding policies to support private sector and to enhance the business environment as well as to protect property rights (together with the development of financial sector and implementation of sound fiscal policies). Still, one can note that the World Governance Indicators' variable 'Political Stability and Absence of Violence/Terrorism' - which measures perceptions of the likelihood of political instability and/or politically motivated violence, including terrorism does not play virtually any role both in the full sample as well as in the sub-sample. One possible explanation relates to that, for this variable, a country that is a functioning democracy, but is wrecked by domestic politically motivated violence, may not score well on this indicator. Nevertheless, at a more profound level, we see this as a supplementary evidence of an impending process, which takes place on 'short-run', between 'policies' (mainly economic-related ones) and 'institutions' in terms of growth-induced effects. However, it seems that this is not the case for other types of policies, such as those promoting gender equality or environmental sustainability: in low-income countries, these types of policies exercise little impact on growth regardless of their democratic status. Nor does it exercise a significant impact a standard economic variable, such as the gross capital formation: if the overall economic environment does not provide enough opportunities, internal investments are less able to act as a growth engine. 


\section{CONCLUSIONS}

We use cross-country data for a sample of 65 low-income (and lower-middle income) countries in order to investigate the relationships between business regulatory environment and growth, in the framework accounting for model uncertainty, i.e. 'Bayesian Model Averaging'. The results suggest a statistically significant positive relationship between the overall quality of business regulatory environment, as captured by the corresponding CPIA indicator, and growth: countries with a higher quality of their business supporting policies are more likely to enjoy higher growth, regardless of their initial level of development. This outcome is found to be robust to various choices of priors' structures.

We also contemplate the existence of some potential endogeneity issues that might emerge in the processes linking business regulations and growth, by involving an BMA model with instrumental variables. While the direct impact of regulations on growth remains significant, its estimated amplitude largely declines once the endogeneity is considered.

Finally, we consider the possibility that 'good' policies might compensate (up to a certain degree) for 'bad' institutions. Indeed, when a sub-sample of countries with lower levels of political participation and freedom of expression and association is considered, then the impact exercised by the quality of business regulations appears to be more pronounced.

Overall, we view such findings as providing an empirical support for the thesis that regulatory policies and their outcomes really matter in explaining growth. However, further research is required for a more detailed analysis of the multiple interactions between policies, institutions and growth.

\section{ACKNOWLEDGEMENT}

This work was supported by a grant from Iceland, Liechtenstein and Norway through the project 15-SEE-PC-RO TIMISOA01 "Opportunities and Challenges for Tertiary Educational System in Promoting Evidence-Informed Good Governance Society - ActiveGovEdu" co-funded from the the EEA Financial Mechanism 2009-2014 - Inter-institutional cooperation projects, Contract no. $2 / 24 / 07.2015$.

\section{REFERENCES}

Adams, S., and Opoku, E.E.0. 2015. "Foreign direct investment, regulations and growth in subSaharan Africa." Economic Analysis and Policy, 47, 48-56. http://doi.org/10.1016/ j.eap.2015.07.001

Alesina, A., and Dollar, D. 2000. "Who Gives Foreign Aid to Whom and Why?" Journal of Economic Growth, 5(1): 33-63. http://doi.org/10.1023/a:1009874203400

Alesina, A., Ozler, S., Roubini, N., and Swagel, P. 1996. "Political Instability and Economic Growth." Journal of Economic Growth, 1: 189-211. doi:10.1007/BF00138862

Alonso, J.A., and Garcimartín, C. 2013. "The determinants of institutional quality. More on the debate." Journal of International Development, 25(2): 206-226. http://doi.org/ 10.1002/jid.1710

Arruñada, B. 2010. "How Doing Business jeopardises institutional reform." European Business Organization Law Review, 10(04): 555-574. doi:10.1017/S1566752909005552

Asiedu, E., and Lien, D. 2011. "Democracy, foreign direct investment and natural resources." Journal of International Economics, 84(1): 99-111. doi:10.1016/j.jinteco.2010.12.001

Austin, G. 2008. "The <<reversal of fortune >> thesis and the compression of history: Perspectives from African and comparative economic history." Journal of International Development, 20(8): 996-1027. doi:10.1002/jid.1510 
Barro, R.J. 2001. "Education and Economic Growth." In: Helliwell J.F. The Contribution of Human and Social Capital to Sustained Economic Growth and Well-Being. OECD

Beugelsdijk, S. 2010. "Entrepreneurial culture, regional innovativeness and economic growth." In Entrepreneurship and Culture (pp. 129-154). doi:10.1007/978-3-540-87910-7_7

Bloom, D., Canning, D., and Chan, K. 2006. Higher Education and Economic Development in Africa.Africa Region Human Development Series. Retrieved from http://www.arp.harvard.edu/Africa HigherEducation/Reports/BloomAndCanning.pdf

Bond, S.R., and Malik, A. 2009. "Natural resources, export structure, and investment." Oxford Economic Papers, 61: 675-702. doi:10.1093/oep/gpp025

Botero, J.C., Djankov, S., La Porta, R., Lopez-de-Silanes, F., and Shleifer, A. 2004. "The Regulation of Labor." Quarterly Journal of Economics, 119(4): 1339-1382. doi:10.1162 /0033553042476215

Busse, M., and Groizard, J. L. 2008. "Foreign direct investment, regulations and growth." World Economy, 31(7): 861-886. http://doi.org/10.1111/j.1467-9701.2008.01106.x

Dawson, J.W. 2006. "Regulation, investment, and growth across countries." Cato Journal, 26(3): 489-509.

Djankov, S., La Porta, R., Lopez-de-Silanes, F., and Shleifer, A. 2002. "The Regulation of Entry." Quarterly Journal of Economics, 117(1): 1-37. doi:10.1162/003355302753399436

Djankov, S., McLiesh, C., and Ramalho, R.M. 2006. "Regulation and growth." Economics Letters, 92(3): 395-401. doi:10.1016/j.econlet.2006.03.021

Eicher, T.S., Papageorgiou, C., and Raftery, A.E. 2011. "Default priors and predictive performance in Bayesian model averaging, with application to growth determinants." Journal of Applied Econometrics, 26(1): 30-55. http://doi.org/10.1002/jae.1112

Feldkircher, M., and Zeugner, S. 2015. Bayesian Model Averaging Library. R package BMS , version 0.34. Retrieved from https://cran.r-project.org/web/packages/BMS/BMS.pdf

Feng, Y. 1997. "Democracy, political stability and economic growth." British Journal of Political Science, 27(3): 391-418. doi:Doi 10.1017/S0007123497000197

Fernandez, C., Ley, E., and Steel, M.F.J. 2001. "Benchmark priors for Bayesian model averaging." Journal of Econometrics, 100(2): 381-427. http://doi.org/10.1016/S0304-4076(00)00076-2

Gyimah-Brempong, K., Paddison, O., and Mitiku, W. 2006. "Higher education and economic growth in Africa." Journal of Development Studies, 42(3): 509-529. doi:10.1080/00220 380600576490

Glaeser, E. L., La Porta, R., Lopez-de-Silanes, F., and Shleifer, A. 2004. "Do institutions cause growth?" Journal of Economic Growth, 9(3): 271-303. http://doi.org/10.1023/ B:JOEG.0000038933.1639 8.ed

Globerman, S., and Shapiro, D. 2002. "Global foreign direct investment flows: The role of governance infrastructure." World Development, 30(11): 1899-1919. http://doi.org/10.1016/S0305-750X(02)00110 -9

Gylfason, T., and Zoega, G. 2006. "Natural Resources and Economic Growth: The Role of Investment." The World Economy, 29(8): 1091-1115. doi:10.1111/j.1467-97 01.2006.00807.x

Haidar, J.I. 2012. "The impact of business regulatory reforms on economic growth." Journal of the Japanese and International Economies, 26(3): 285-307. doi:10.1016/ j.jjie.2012.05.004

Haltiwanger, J., Scarpetta, S., and Schweiger, H. 2014. "Cross country differences in job reallocation: The role of industry, firm size and regulations." Labour Economics, 26: 11-25. doi:10.1016/j.labeco.2013.10.001

Hanusch, M. 2012. "The Doing Business Indicators, Economic Growth and Regulatory Reform." Policy Research Working Papers, (August), 1-21. doi:http://dx.doi.org/ 10.1596/1813-94506176

Harstad, B., and Svensson, J. 2011. "Bribes, Lobbying, and Development." American Political Science Review, 105(01): 46-63. doi:10.1017/S0003055410000523

Hoeting, J.A., Madigan, D., Raftery, A.E., and Volinsky, C.T. 1999. "Bayesian model averaging: A tutorial." Statistical Science, 14(4): 382-401. doi:10.2307/2676803 
Horvath, R. 2013. "Does trust promote growth?" Journal of Comparative Economics, 41(3): 777788. doi:10.1016/j.jce.2012.10.006

Irwin, D. 2014. "Doing business: Using ratings to drive reform." Journal of International Development, 26(5): 658-667. doi:10.1002/jid.2906

Islam, R., and Montenegro, C.E. 2002. "What Determines the Quality of Institutions?" Background Paper for the World Development Report 2002: Building Institutions for Markets, (January).

Jong-A-Pin, R. 2009. "On the measurement of political instability and its impact on economic growth." European Journal of Political Economy, 25(1): 15-29. doi:10.1016/ j.ejpoleco.2008.09.010

Karl, A., and Lenkoski, A. 2012. Instrumental Variable Bayesian Model Averaging via Conditional Bayes Factors. Arxiv Preprint. Retrieved from http://arxiv.org/abs/1202.5846

Karl, A., Lenkoski, A., \&Neudecker, A. (2015). Bayesian Instrumental Variable Estimation and Model Determination via Conditional Bayes Factors. R package ivbma, version 1.05. Retrieved from https://cran.r-project.org/web/packages/ivbma/ivbma.pdf

Kaufmann, D., Kraay, A., and Mastruzzi, M. 2011. "The Worldwide Governance Indicators: Methodology and Analytical Issues." Hague Journal on the Rule of Law, 3(02): 220-246. http://doi.org/ 10.1017/S1876404511200046

Kaufmann, D., Kraay, A., and Mastruzzi, M. 2015. Worldwide Governance Indicators. Retrieved from http://info.worldbank.org/governance/wgi/index.aspx\#home

Kolko, J., Neumark, D., and Mejia, M.C. 2011. "Public Policy, State Business Climates, and Economic Growth. " NBER Working Papers. Retrieved from http://www.nber.org/ papers/w16968

Kruss, G., McGrath, S., Petersen, I., and Gastrow, M. 2015. "Higher education and economic development: The importance of building technological capabilities." International Journal of Educational Development, 43: 22-31. doi:10.1016/j.ijedudev.2015.04.011

Liang, F., Paulo, R., Molina, G., Clyde, M., and Berger, J.0. 2008. "Mixtures of g priors for Bayesian variable selection." Journal of the American Statistical Association, 103(481): 410-423. http://doi.org/Doi 10.1198/016214507000001337

Leite, C.A.D.C., and Weidmann, J. 1999. "Does mother nature corrupt? Natural resources, corruption, and economic growth." IMF Working Paper No. 99/85. doi:10.2139/ ssrn.259928

Lin, T.-C. 2004. "The role of higher education in economic development: an empirical study of Taiwan case." Journal of Asian Economics, 15(2): 355-371. doi:10.1016/ j.asieco.2004.02.006

Masanjala, W.H., and Papageorgiou, C. 2008. "Rough and lonely road to prosperity: A reexamination of the sources of growth in Africa using Bayesian model averaging." Journal of Applied Econometrics, 23(5): 671-682. http://doi.org/10.1002/jae.1020

Messaoud, B., and Teheni, Z.E.G. 2014. "Business regulations and economic growth: What can be explained? " International Strategic Management Review, 2(2): 69-78. doi:10.1016/ j.ism.2014.03.001

Moral-Benito, E. 2015. "Model averaging in economics." Journal of Economic Surveys, 29(1):4675. http://doi.org/10.1111/joes.12044

Morris, R., and Aziz, A. 2011. "Ease of doing business and FDI inflow to Sub-Saharan Africa and Asian countries." Cross Cultural Management: An International Journal, 18(4): 400-411. http://doi.org/10.1108/13527601111179483

Munemo, J. 2014. "Business start-up regulations and the complementarity between foreign and domestic investment. " Review of World Economics, 150(4):745-761. http://doi.org/10.1007/s10290-014-0189-2

Murphy, D.J., and Hall, C.A.S. 2011. "Energy return on investment, peak oil, and the end of economic growth." Annals of the New York Academy of Sciences, 1219(1):52-72. doi:10.1111/j.1749-6632.2010.05940.x

Nicoletti, G., and Scarpetta, S. 2003. "Regulation, productivity and growth: OECD evidence. " Economic Policy, 18(36): 9-72. doi:10.1111/1468-0327.00102 
Persson, T., and Tabellini, G. 2009. "Democratic capital: the nexus of political and economic change." American Economic Journal: Macroeconomics, 12(1): 88-126. doi:10.1257/ mac.1.2.88

Price, G. 2003. "Economic Growth in a Cross-section of Nonindustrial Countries: Does Colonial Heritage Matter for Africa?" Review of Development Economics, 7(3): 478-495. doi:10.1111/1467-9361.00204

Przeworski, A., and Limongi, F. 1993. "Political Regimes and Economic Growth. " The Journal of Economic Perspectives, 7(3): 51-69. doi:10.1257/jep.7.3.51

Rigobon, R., and Rodrik, D. 2005. "Rule of law, democracy, openness, and income: Estimating the interrelationships." Economics of Transition, 13(3): 533-564. http://doi.org/10.1111/j.1468-0351.2005. 00226.x

Rossi, P.E., Allenby, G.M., and McCulloch, R. 2006. "Bayesian Statistics and Marketing. " Bayesian Statistics and Marketing. doi:10.1002/0470863692

Younis, M., Lin, X.X., Sharahili, Y., and Selvarathinam, S. 2008. "Political stability and economic growth in Asia. " American Journal of Applied Sciences, 5(3): 203-208. doi:10.3844/ajassp.2008.203.208

Williamson, C.R., and Mathers, R.L. 2010. "Economic freedom, culture, and growth. " Public Choice, 148(May): 313-335. doi:10.1007/s11127-010-9656-z

Wolf, A. 2002. "Does education matter? Myths about education and economic growth. " Perspectives: Policy and Practice in Higher Education, 6(4): 115-118. doi:10.1080/ 136031002320635023

World Bank. 2014. CPIA 2014 criteria. Washington, D.C.: World Bank Group. Retrieved from http://documents.worldbank.org/curated/en/2015/06/24698216/cpia-2014-criteria

World Bank. 2015. World Development Indicators 2015. World Bank. doi:10.1596/978-0-82137386-6

Zeugner, S. 2011. Bayesian Model Averaging with BMS for BMS Version 0.3.0. Retrieved from http://bms.zeugner.eu 


\section{APPENDIX}

Table A.1. List of countries included in the dataset

\begin{tabular}{|l|l|l|l|}
\hline Bangladesh & Ethiopia & Maldives & Sierra Leone \\
\hline Benin & Gambia, The & Mali & Solomon Islands \\
\hline Bhutan & Ghana & Mauritania & Sri Lanka \\
\hline Bolivia & Grenada & Moldova & St. Lucia \\
\hline Burkina Faso & Guinea & Mongolia & St. Vincent and the Grenadines \\
\hline Burundi & Guinea-Bissau & Mozambique & Sudan \\
\hline Cabo Verde & Guyana & Nepal & Tajikistan \\
\hline Cambodia & Haiti & Nicaragua & Tanzania \\
\hline Cameroon & Honduras & Niger & Togo \\
\hline Central African Republic & Kenya & Nigeria & Tonga \\
\hline Chad & Kiribati & Pakistan & Uganda \\
\hline Comoros & Kyrgyz Republic & Papua New Guinea & Uzbekistan \\
\hline Congo, Dem. Rep. & Lao PDR & Rwanda & Vanuatu \\
\hline Congo, Rep. & Lesotho & Samoa & Vietnam \\
\hline Cote d'Ivoire & Madagascar & Sao Tome and Principe & Yemen, Rep. \\
\hline Djibouti & Malawi & Senegal & Zambia \\
\hline Dominica & & & \\
\hline
\end{tabular}

Table A.2. List of variables

\begin{tabular}{|c|c|c|}
\hline Variable & Content & Source of data \\
\hline \multicolumn{3}{|c|}{ Dependent variable } \\
\hline $\begin{array}{l}\text { GDP growth (annual } \\
\% \text { ) }\end{array}$ & $\begin{array}{l}\text { Annual percentage growth rate of GDP at market prices based on } \\
\text { constant local currency. Aggregates are based on constant } 2005 \text { U.S. } \\
\text { dollars. GDP is the sum of gross value added by all resident } \\
\text { producers in the economy plus any product taxes and minus any } \\
\text { subsidies not included in the value of the products. It is calculated } \\
\text { without making deductions for depreciation of fabricated assets or } \\
\text { for depletion and degradation of natural resources (2005-2014 } \\
\text { averages) }\end{array}$ & $\begin{array}{l}\text { World Bank Group, } \\
\text { World Development } \\
\text { Indicators database } \\
\text { (http://databank.wo } \\
\text { rldbank.org/data/re } \\
\text { ports.aspx?source= } \\
\text { world-development- } \\
\text { indicators) }\end{array}$ \\
\hline \multicolumn{3}{|c|}{ CPIA criteria } \\
\hline $\begin{array}{l}\text { CPIA business } \\
\text { regulatory } \\
\text { environment rating }\end{array}$ & $\begin{array}{l}\text { The extent to which the legal, regulatory, and policy environments } \\
\text { help or hinder private businesses in investing, creating jobs, and } \\
\text { becoming more productive. }\end{array}$ & \multirow{7}{*}{$\begin{array}{l}\text { World Bank Group, } \\
\text { CPIA database } \\
\text { (http://databank.wo } \\
\text { rldbank.org/data/re } \\
\text { ports.aspx?source=c } \\
\text { ountry-policy-and- } \\
\text { institutional- } \\
\text { assessment) }\end{array}$} \\
\hline $\begin{array}{l}\text { CPIA building human } \\
\text { resources rating }\end{array}$ & $\begin{array}{l}\text { National policies and public and private sector service delivery that } \\
\text { affect the access to and quality of health and education services, } \\
\text { including prevention and treatment of HIV/AIDS, tuberculosis, and } \\
\text { malaria. }\end{array}$ & \\
\hline $\begin{array}{l}\text { CPIA debt policy } \\
\text { rating }\end{array}$ & $\begin{array}{l}\text { Whether the debt management strategy is conducive to minimizing } \\
\text { budgetary risks and ensuring long-term debt sustainability. }\end{array}$ & \\
\hline $\begin{array}{l}\text { CPIA efficiency of } \\
\text { revenue } \\
\text { mobilization rating }\end{array}$ & $\begin{array}{l}\text { The overall pattern of revenue mobilization--not only the de facto } \\
\text { tax structure, but also revenue from all sources as actually collected. }\end{array}$ & \\
\hline $\begin{array}{l}\text { CPIA equity of public } \\
\text { resource use rating }\end{array}$ & $\begin{array}{l}\text { The extent to which the pattern of public expenditures and revenue } \\
\text { collection affects the poor and is consistent with national poverty } \\
\text { reduction priorities. }\end{array}$ & \\
\hline $\begin{array}{l}\text { CPIA financial sector } \\
\text { rating }\end{array}$ & $\begin{array}{l}\text { The structure of the financial sector and the policies and regulations } \\
\text { that affect it. }\end{array}$ & \\
\hline $\begin{array}{l}\text { CPIA fiscal policy } \\
\text { rating }\end{array}$ & $\begin{array}{l}\text { The short- and medium-term sustainability of fiscal policy (taking } \\
\text { into account monetary and exchange rate policy and the } \\
\text { sustainability of the public debt) and its impact on growth. }\end{array}$ & \\
\hline
\end{tabular}




\begin{tabular}{|c|c|c|}
\hline $\begin{array}{l}\text { CPIA gender equality } \\
\text { rating }\end{array}$ & $\begin{array}{l}\text { The extent to which the country has installed institutions and } \\
\text { programs to enforce laws and policies that promote equal access for } \\
\text { men and women in education, health, the economy, and protection } \\
\text { under law. }\end{array}$ & \\
\hline $\begin{array}{l}\text { CPIA } \\
\text { macroeconomic } \\
\text { management rating }\end{array}$ & $\begin{array}{l}\text { The monetary, exchange rate, and aggregate demand policy } \\
\text { framework. }\end{array}$ & \\
\hline $\begin{array}{l}\text { CPIA policy and } \\
\text { institutions for } \\
\text { environmental } \\
\text { sustainability rating }\end{array}$ & $\begin{array}{l}\text { The extent to which environmental policies foster the protection } \\
\text { and sustainable use of natural resources and the management of } \\
\text { pollution. }\end{array}$ & \\
\hline $\begin{array}{l}\text { CPIA property rights } \\
\text { and rule-based } \\
\text { governance rating }\end{array}$ & $\begin{array}{l}\text { The extent to which private economic activity is facilitated by an } \\
\text { effective legal system and rule-based governance structure in which } \\
\text { property and contract rights are reliably respected and enforced. }\end{array}$ & \\
\hline $\begin{array}{l}\text { CPIA quality of } \\
\text { budgetary and } \\
\text { financial } \\
\text { management rating }\end{array}$ & $\begin{array}{l}\text { The extent to which there is a comprehensive and credible budget } \\
\text { linked to policy priorities, effective financial management systems, } \\
\text { and timely and accurate accounting and fiscal reporting, including } \\
\text { timely and audited public accounts. }\end{array}$ & \\
\hline $\begin{array}{l}\text { CPIA quality of } \\
\text { public } \\
\text { administration } \\
\text { rating }\end{array}$ & $\begin{array}{l}\text { The extent to which civilian central government staff is structured } \\
\text { to design and implement government policy and deliver services } \\
\text { effectively. }\end{array}$ & \\
\hline $\begin{array}{l}\text { CPIA social } \\
\text { protection and } \\
\text { labour rating }\end{array}$ & $\begin{array}{l}\text { Government policies in social protection and labour market } \\
\text { regulations that reduce the risk of becoming poor, assist those who } \\
\text { are poor to better manage further risks, and ensure a minimal level } \\
\text { of welfare to all people. }\end{array}$ & \\
\hline CPIA trade rating & How the policy framework fosters trade in goods. & \\
\hline $\begin{array}{l}\text { CPIA transparency, } \\
\text { accountability, and } \\
\text { corruption in the } \\
\text { public sector rating }\end{array}$ & $\begin{array}{l}\text { The extent to which the executive can be held accountable for its use } \\
\text { of funds and for the results of its actions by the electorate and by the } \\
\text { legislature and judiciary, and the extent to which public employees } \\
\text { within the executive are required to account for administrative } \\
\text { decisions, use of resources, and results obtained. The three main } \\
\text { dimensions assessed here are the accountability of the executive to } \\
\text { oversight institutions and of public employees for their } \\
\text { performance, access of civil society to information on public affairs, } \\
\text { and state capture by narrow vested interests. }\end{array}$ & \\
\hline \multicolumn{3}{|c|}{ Economic and social variables } \\
\hline $\begin{array}{l}\text { GNI per capita, PPP } \\
\text { (constant } 2011 \\
\text { international \$) }\end{array}$ & $\begin{array}{l}\text { GNI per capita based on purchasing power parity (PPP). PPP GNI is } \\
\text { gross national income (GNI) converted to international dollars using } \\
\text { purchasing power parity rates. An international dollar has the same } \\
\text { purchasing power over GNI as a U.S. dollar has in the United States. } \\
\text { GNI is the sum of value added by all resident producers plus any } \\
\text { product taxes (less subsidies) not included in the valuation of output } \\
\text { plus net receipts of primary income (compensation of employees } \\
\text { and property income) from abroad. Data are in constant } 2011 \\
\text { international dollars. }\end{array}$ & \multirow[t]{4}{*}{$\begin{array}{l}\text { World Bank Group, } \\
\text { World Development } \\
\text { Indicators database } \\
\text { (http://databank.wo } \\
\text { rldbank.org/data/re } \\
\text { ports.aspx?source= } \\
\text { world-development- } \\
\text { indicators) }\end{array}$} \\
\hline $\begin{array}{l}\text { Gross capital } \\
\text { formation }(\% \text { of } \\
\text { GDP) }\end{array}$ & $\begin{array}{l}\text { Gross capital formation consists of outlays on additions to the fixed } \\
\text { assets of the economy plus net changes in the level of inventories. } \\
\text { Fixed assets include land improvements; plant, machinery, and } \\
\text { equipment purchases; and the construction of roads, railways, and } \\
\text { the like, including schools, offices, hospitals, private residential } \\
\text { dwellings, and commercial and industrial buildings. Inventories are } \\
\text { stocks of goods held by firms to meet temporary }\end{array}$ & \\
\hline $\begin{array}{l}\text { Total natural } \\
\text { resources rents }(\% \\
\text { of GDP) }\end{array}$ & $\begin{array}{l}\text { The sum of oil rents, natural gas rents, coal rents (hard and soft), } \\
\text { mineral rents, and forest rents. }\end{array}$ & \\
\hline $\begin{array}{l}\text { Foreign direct } \\
\text { investment, net } \\
\text { inflows (\% of GDP) }\end{array}$ & $\begin{array}{l}\text { Foreign direct investment are the net inflows of investment to } \\
\text { acquire a lasting management interest ( } 10 \text { percent or more of voting } \\
\text { stock) in an enterprise operating in an economy other than that of } \\
\text { the investor. It is the sum of equity capital, reinvestment of earnings, } \\
\text { other long-term capital, and short-term capital as shown in the } \\
\text { balance of payments. This series shows net inflows (new investment }\end{array}$ & \\
\hline
\end{tabular}




\begin{tabular}{|c|c|c|}
\hline & $\begin{array}{l}\text { inflows less disinvestment) in the reporting economy from foreign } \\
\text { investors, and is divided by GDP. }\end{array}$ & \\
\hline $\begin{array}{l}\text { School enrolment, } \\
\text { tertiary (\% gross) }\end{array}$ & $\begin{array}{l}\text { Gross enrolment ratio is the ratio of total enrolment, regardless of } \\
\text { age, to the population of the age group that officially corresponds to } \\
\text { the level of education shown. Tertiary education, whether or not to } \\
\text { an advanced research qualification, normally requires, as a } \\
\text { minimum condition of admission, the successful completion of } \\
\text { education at the secondary level. }\end{array}$ & \\
\hline \multicolumn{3}{|c|}{ Other policies and institutional variables } \\
\hline $\begin{array}{l}\text { Political Stability } \\
\text { and Absence of } \\
\text { Violence/Terrorism }\end{array}$ & $\begin{array}{l}\text { Measures perceptions of the likelihood of political instability and/or } \\
\text { politically-motivated violence, including terrorism. Estimate gives } \\
\text { the country's score on the aggregate indicator, in units of a standard } \\
\text { normal distribution, i.e. ranging from approximately }-2.5 \text { to } 2.5 \text {. }\end{array}$ & \multirow{2}{*}{$\begin{array}{l}\text { World Bank Group, } \\
\text { Worldwide } \\
\text { Governance } \\
\text { Indicators database } \\
\text { (http://databank.wo } \\
\text { rldbank.org/data/re } \\
\text { ports.aspx?source= } \\
\text { worldwide- } \\
\text { governance- } \\
\text { indicators) }\end{array}$} \\
\hline $\begin{array}{l}\text { Voice and } \\
\text { Accountability }\end{array}$ & $\begin{array}{l}\text { Captures perceptions of the extent to which a country's citizens are } \\
\text { able to participate in selecting their government, as well as freedom } \\
\text { of expression, freedom of association, and a free media. Estimate } \\
\text { gives the country's score on the aggregate indicator, in units of a } \\
\text { standard normal distribution, i.e. ranging from approximately }-2.5 \\
\text { to } 2.5 \text {. }\end{array}$ & \\
\hline \multicolumn{3}{|c|}{ Cultural variable } \\
\hline $\begin{array}{l}\text { English language (as } \\
\text { first or second } \\
\text { language) }\end{array}$ & $\begin{array}{l}\text { Dummy for English language as a first (or second) spoken } \\
\text { language in the country (" } 1 \text { ") }\end{array}$ & $\begin{array}{l}\text { Central Intelligence } \\
\text { Agency, The World } \\
\text { Fact book, } \\
\text { (https://www.cia.go } \\
\text { v/library/publicatio } \\
\text { ns/the-world- } \\
\text { factbook/fields/209 } \\
\text { 8.html) }\end{array}$ \\
\hline
\end{tabular}

\begin{tabular}{l|l} 
Article history: & Received: November 19, 2018
\end{tabular}

Accepted: December 21, 2018 